\section{Indian anaemia}

\section{Salt as iron vehicle}

\section{New Delhi}

AFTER nearly eight years of research, the National Institute of Nutrition (NIN) in Hyderabad has found a practical measure to control iron deficiency anaemia (IDA), which afflicts more than half of India's rural population, mostly women. At NIN's recommendation, the Indian Government is taking steps to launch a national anaemia control programme based on iron fortified common salt (IFS) for the entire population.

The widespread prevalence of this anaemia is believed to be due to poor absorption of iron from the millet-based diet consumed in India, aggravated by the inadequate diet of the poor. Under Indian conditions, salt is an ideal vehicle for supplementing dietary iron. It is consumed by all and manufactured in only a very few places, where iron fortification facilities can easily be added.

NIN's choice of iron compound was ferrous sulphate, which is readily utilized by the body. The snag is that ferrous sulphate alters the colour of the salt. After a series of laboratory studies, NIN has devised a preparation that remains stable for eight months without change of colour or deterioration in quality. The formula: $3.5 \mathrm{mg}$ of ferrous sulphate, $3.5 \mathrm{mg}$ of orthophosphoric acid (which prevents colour change) and $5 \mathrm{mg}$ of sodium acid sulphate (which improves the absorption of iron) in each gram of powdered salt.

Two long-term community studies have been carried out to demonstrate the effectiveness of IFS in preventing and controlling anaemia. In one study, IFS was given for 18 months to children of a residential school between 5 and 15 years of age. In another study, sponsored by UNICEF, IFS was supplied to rural households near Hyderabad and Calcutta and to urban dwellers in Madras city. In both studies, according to NIN, IFS was effective and free from side effects.

Even so, experts have pointed out that use of IFS for the entire population may not be without risk. It is feared that intake of extra iron over and above that derived from diet might increase the risk of infection. NIN, however, says that IFS consumption by normal people is safe and that, on the contrary, the available evidence shows that extra iron may actually improve "immune status and other functional capacities of the population".

The Government of India is at present also supplying iodized salt for the control of goitre in endemic areas in the subHimalayan belt. Since anaemia is also prevalent in that region, NIN is hoping to tackle both problems with salt fortified with both iron and iodide using a new formula now being evaluated.

Industrial research

\title{
US tax credits a failure
}

\section{Washington}

WHAT seemed to be a straightforward scheme to encourage companies to put more money into research by offering special tax incentives has turned out to be a major disappointment, and it now seems likely that the four-year test of the programme will not be extended.

The United States thus appears ready to follow in the footsteps of Sweden, which recently abandoned its programme of tax credits for spending on research and development after a ten-year trial produced little evidence of any benefit to research activities in the private sector.

The US programme, which is costing the Treasury $\$ 1,000-£ 1,500$ million annually, allows companies to claim a 25 per cent credit for any expenditures on research and development that exceed the average of such expenditures for the preceding three years. The credit, which is applied directly against the company's tax liability, is in addition to the usual deduction against revenues allowed for all business expenses. In-house research costs plus 65 per cent of contracts (including contracts to universities) count towards the total.

The 1981 legislation that established the programme also allowed "enhanced deductions" for companies donating stateof-the-art scientific equipment to educational institutions. Normally, companies can claim only their manufacturing costs when they make charitable donations of their products; the 1981 rule allows them to claim the full wholesale price so long as the equipment is new and working and the recipient is a college or university.

In practice, the results have fallen far short of the promise. A survey recently conducted by the General Accounting Office (GAO) found a significant number of service companies claiming the tax credit, generally for their "research" efforts in developing software. An earlier survey by the Treasury Department found fast-food restaurants, bakeries, home builders, publishing houses and movie studios among them. These non-manufacturing and non-utility firms reported a suspiciously large growth in their research and development activities of 91 per cent between 1980 , before the credit was introduced, and 1981.

Even among the manufacturing companies that claimed the bulk of the credits, there is little evidence that they were heavily influenced by it. In a nonscientific sampling of 86 companies, GAO found that slightly over one-third actually acknowledged that the credit had had no effect whatsoever on their research programme. Other statistics tend to confirm this conclusion more generally. According to Robert Eisner, an economist at Northwestern University, much of the increase reported from 1980 to 1981 and subsequently was apparently the result of "creative accounting" — redefining as research certain types of expenditures that were not considered as such in calculating the base rate of the previous three years.

Another factor behind the large amounts of credits being claimed was inflation. Companies were allowed to claim a credit for a nominal increase in research expenditures even when the increase only kept pace with inflation.

A survey conducted by Edwin Mansfield, an economist at the University of Pennsylvania, of almost 800 companies with research budgets greater than \$1 million showed that by their own estimates they would have spent only 1.2 per cent less in 1982 in the absence of the credits. Mansfield concluded that it was very unlikely that the tax-credits-induced research and development in 1983 exceeded $\$ 683$ million, while costing the Treasury $\$ 1,000$ million in lost revenue.

It comes as no surprise that the major industrial trade associations are staunchly behind a continuation of the programme. (A representative of the National Food Processors Association appeared before the House of Representatives Ways and Means Committee to spread the word that "some of our innovative packaging and processing technologies might still be something in our future" were it not for the tax credits.)

A group called the National Coalition for Science and Technology (NCST), a self-styled "science lobby" representing 1,000 scientists and engineers and about two dozen high-technology companies, also supports the programme. NCST's executive director, Marc Rosenberg, argues that four years is simply not enough time to expect a measurable effect from the programme, given the lengthy advance planning that goes into research decisions, and that all that has been done so far is to reward companies ex post facto for decisions taken before the credit was enacted. Uncertainty over the extension of the credit has also limited its effectiveness, he said. The credit is set to expire at the end of next year. The Senate has passed an extension; the House has balked, and is considered unlikely to act this year.

If a bill is passed, it is likely to include language that would tighten the definition of qualifying research to eliminate marketing research (which appears to have slipped in under the present rules) and emphasize technologically-based products and processes. But faced with the prospect of having to find additional revenue to reduce the $\$ 200,000$ million annual deficit, the Ways and Means Committee is not going to go easy next year on a bill that grants a $\$ 1,000$ million tax break to business.

Stephen Budiansky 